\title{
Strategi Pengembangan Karier PNS Fungsional Umum di Institut Pertanian Bogor
}

\section{Career Development Strategies of the General Functional Civil Servants in Bogor Agricultural University}

\author{
Gandi Aria Wijaya ${ }^{1}$, M. Syamsul Maarif ${ }^{2}$, Anggraini Sukmawati ${ }^{3}$ \\ ${ }^{1}$ Fakultas Pertanian, Institut Pertanian Bogor, Bogor \\ ${ }^{2}$ Departemen Teknologi Industri Pertanian, Fakultas Teknologi Pertanian, Institut Pertanian Bogor, Bogor \\ ${ }^{3}$ Departemen Manajemen, Fakultas Ekonomi dan Manajemen, Institut Pertanian Bogor, Bogor
}

\begin{abstract}
The main issues in the field of human resources is a state civil officials on the quality and distribution of civil servants, therefore we need a research to know the civil servant career development strategy. Process and career development should be professional career development oriented of civil servants which means not only the structural purpose, but also to developing expertise towards functional. Thus, the position of the functional has a role as equal partners in a structural position. The purpose of this study is to identify what are the main priorities of the factors, actors and objectives as well as the recommendation of alternative strategies are most influential on the development of common functional civil servants career in IPB. The research was conducted at IPB and the Bureau of Personnel Culture and Education Ministry Secretariat using descriptive analysis and AHP (Analytical Hierarchy Process) methods. The results of the descriptive analysis is from 1.500 civil servants education personnel only $14,3 \%$ certain functional officials in IPB, thus 83,7\% is common functional PNS included structural officials which selectively will be converted to be specific functional civil service officials. Results obtained from AHP processing the alternative strategy most recommended is the establishment of assessment centers (0,482) by actor Vice Rector of Resources and Strategic Studies (0,498), through the strengthening of organizational factors (0,357) with the aim of increasing professionalism (0,600), that all are the main priorities which influence to the development of a common functional IPB civil servants career:
\end{abstract}

Keywords : civil servant quality and distribution, professionalism, carrier development strategy, assesment center

\begin{abstract}
Abstrak
Permasalahan utama di bidang sumberdaya manusia aparatur sipil negara adalah pada kualitas dan distribusi PNS, oleh karena itu diperlukan suatu penelitian untuk mengetahui strategi pengembangan karier PNS. Proses dan pengembangan karier harus berorientasi profesionalisme yang berarti pengembangan karier PNS tidak hanya ke arah struktural, tetapi juga mengembangkan keahlian ke arah fungsional. Dengan demikian, posisi fungsional memiliki peran sebagai equal partner in structural position. Tujuan penelitian ini adalah mengidentifikasi apa saja prioritas utama dari faktor, aktor dan tujuan serta rekomendasi alternatif strategi apa yang paling berpengaruh terhadap pengembangan karier PNS fungsional umum di IPB. Penelitian dilakukan di IPB dan Biro Kepegawaian Setjen Kemendikbud menggunakan metode analisis deskriptif dan AHP (Analytical Hierarchy Process). Dari hasil analisis deskriptif dari 1.500 orang PNS tenaga kependidikan hanya ada $14,3 \%$ pejabat fungsional tertentu di IPB, dengan demikian $83,7 \%$ adalah PNS fungsional umum termasuk pejabat struktural yang secara selektif dapat dialihfungsikan menjadi PNS pejabat fungsional tertentu. Dari pengolahan AHP didapatkan hasil alternatif strategi yang paling direkomendasikan adalah pembentukan assesment center $(0,482)$ oleh aktor Wakil Rektor Sumberdaya dan Kajian Strategis $(0,498)$, melalui penguatan faktor pengorganisasian $(0,357)$ dengan tujuan meningkatkan profesionalisme $(0,600)$, hal itu semua adalah merupakan prioritas utama yang berpengaruh bagi pengembangan karier PNS fungsional umum IPB.
\end{abstract}

Kata kunci: kualitas dan distribusi PNS, profesionalisme, strategi pengembangan karier, assesment center.

\section{Pendahuluan}

Setiap organisasi selalu dituntut untuk dapat beradaptasi dan bergerak cepat dalam lingkungan yang dinamis. Perubahan dalam struktur organisasi membawa dampak terutama bagi pengembangan karier individu pegawai. Organisasi akan memanfaatkan dan mendayagunakan keunggulan kompetensi dan kinerja pegawai untuk mencapai tujuan strategis dengan memberikan kesempatan dan memfasilitasi setiap pegawai untuk mengembangkan kariernya (Ma'arif, 2012).

Persoalan utama di bidang Sumberdaya Manusia (SDM) aparatur adalah pada kualitas dan distribusi PNS. Oleh karena itu, dibutuhkan analisis atas kebutuhan PNS di setiap instansi, agar komposisi PNS pada

${ }^{1}$ Korespondensi penulis

E-mail: ganirianti@gmail.com 
setiap instansi baik untuk jabatan pelaksana tugas pokok dan penunjang benar-benar didasarkan atas kebutuhan instansi. Dibutuhkan upaya pengelolaan SDM aparatur dimulai dari perekrutan, pembinaan, penempatan, mutasi, dan promosi (LKIP Deputi Program dan Reformasi Birokrasi Kemenpan, 2012).

Sistem kepegawaian negara terdiri dari tiga status tugas/jabatan yaitu struktural, fungsional tertentu dan fungsional umum. Secara umum pada tahap penerimaan (antara golongan I/a sampai dengan III/a), setiap PNS masuk pada status fungsional umum, selanjutnya mereka dapat memilih karier apakah menjadi PNS pejabat struktural atau menjadi PNS pejabat fungsional tertentu. Di Indonesia pada awal tahun 2013 persentase PNS struktural adalah $5,34 \%$, fungsional tertentu $50,41 \%$ dan fungsional umum 44,26\% seperti dapat dilihat pada Gambar 1. Berdasarkan data tersebut pemerintah berencana untuk meningkatkan profesionalisme PNS dengan mengalihfungsikan 44,26\% PNS fungsional umum menjadi kepada fungsi sesuai dengan latar belakang pengalaman kerja, pendidikan terakhir dan minatnya yaitu menjadi PNS fungsional tertentu menjadi di atas $50,41 \%$.

Data dalam Rencana Strategis (Renstra) SDM IPB 2012 per Maret 2012 menunjukkan bahwa, dari 1654 orang PNS tenaga kependidikan IPB berdasarkan tingkat pendidikan terakhirnya, ternyata hanya sebesar 18,12\% PNS tenaga kependidikan IPB baik struktural maupun fungsional yang berpendidikan S1. Kemudian berdasarkan jenis jabatan PNS Tenaga Kependidikan IPB per 1 September 2013 data yang diperoleh dari Direktorat SDM IPB adalah:

Untuk menghadapi rencana pemerintah untuk

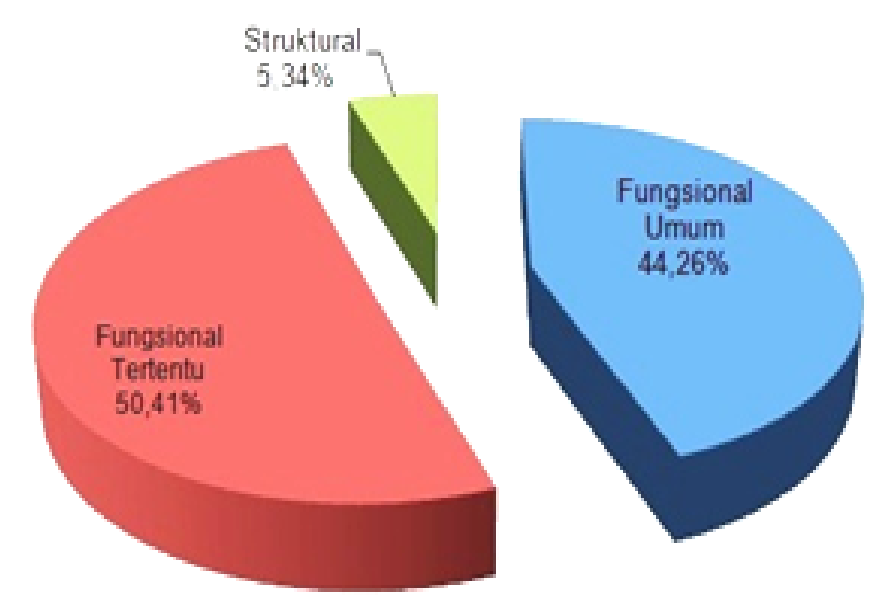

Gambar 1 Jumlah PNS menurut Jenis Jabatan per 1 Januari 2013

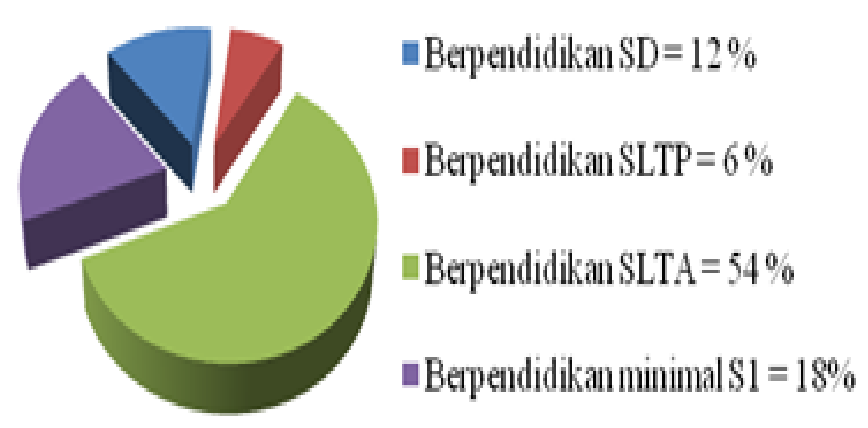

Gambar 2 PNS Tenaga Kependidikan IPB menurut Tingkat Pendidikan

meningkatkan profesionalisme PNS, maka IPB sebagai organisasi mempersiapkan hal tersebut melalui pengalihfungsian PNS dari fungsional umum menjadi fungsional tertentu. Pengalihfungsian tersebut tentu akan mempengaruhi budaya dan struktur organisasi IPB. Permasalahan selanjutnya adalah bagaimana strategi pengembangan karier PNS fungsional umum di IPB? serta faktor, aktor, tujuan dan alternatif strategi apakah yang mempengaruhi pengembangan karier PNS fungsional umum di IPB?

Menecrmati permasalahan terkait upaya peningkatan profesionalitas PNS di IPB, maka tujuan penelitian ini adalah: (1) mengidentifikasi faktor, aktor, tujuan dan alternatif strategi pengembangan karier PNS fungsional umum di IPB dan (2) memformulasikan rekomendasi alternatif strategi yang paling berpengaruh terhadap pengembangan karier PNS fungsional umum di IPB

Pendekatan penelitian secara deskriptif analisis dipilih untuk menjelaskan subjek penelitian berdasarkan data dari variabel yang diperoleh. Analisis ini menurut Azwar (2007) tidak dimaksudkan untuk pengujian

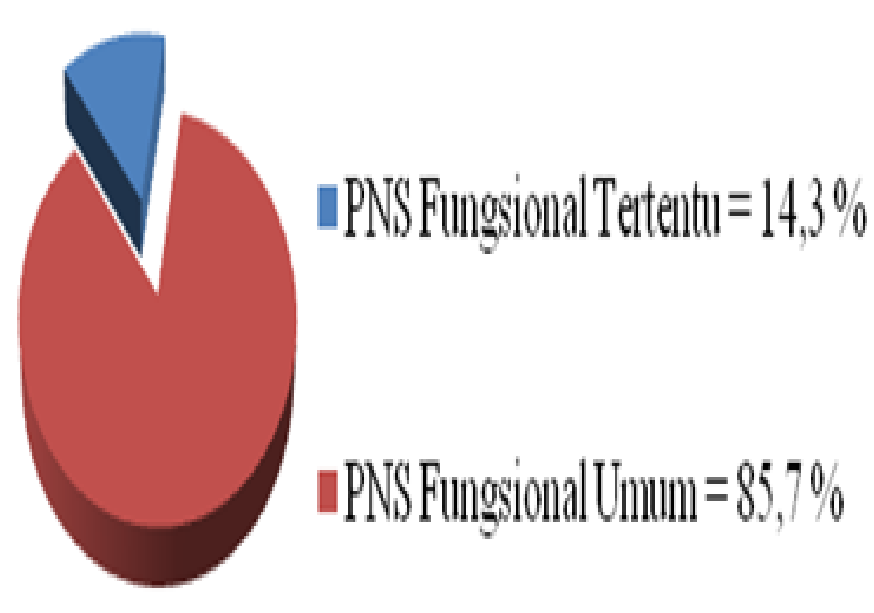

Gambar 3 Jenis Jabatan PNS Tenaga Kependidikan IPB tahun 2013 
hipotesis. Adapun penyusunan strategi pengembangan karier PNS berkaitan pula dengan misi yang komprehensif dan tegas, keberhatihatian dalam menilai lingkungan eksternal serta keterbukaan organisasi dalam menyadari kekuatan dan kelemahannya, merujuk pendapat Hubeis dan Najib (2008).

Pengembangan karier diharapkan menjadi salah satu kunci penting bagi pegawai dan manajemen dalam mewujudkan efektifitas individu pegawai dan organisasi dalam mencapai tujuannya. Visi dalam konteks pembangunan bidang kepegawaian di masa depan adalah mempersiapkan PNS yang profesional, mampu bersaing dan mampu mengantisipasi perkembangan dunia yang pesat di berbagai aspek kehidupan sehingga mampu meningkatkan mutu pelayanan serta kinerja yang tinggi. (Ma'arif, 2010).

Organisasi dan strukturnya selalu dituntut untuk dapat beradaptasi dan bergerak cepat dalam lingkungan yang dinamis. Perubahan dalam struktur organisasi membawa dampak bagi setiap individu yang berada dalamorganisasitersebut,terutamadalampengembangan karier individu pegawai. Setiap pegawai selalu dituntut untuk mengembangkan dan merealisasikan kompetensi yang dimilikinya. Dilain pihak, organisasi akan memanfaatkan dan memberdayagunakan keunggulan kompetensi dan kinerja pegawai untuk mencapai tujuan strategis dengan memberikan kesempatan dan memfasilitasi setiap pegawai untuk mengembangkan kariernya (Ma'arif, 2012).

Berdasarkan konsep pengembangan karier tersebut maka dibuat kerangka penelitian seperti pada Gambar 4. Penerapan sistem karier dengan tujuan untuk menciptakan profesionalisme PNS paling tidak yang harus dilakukan adalah: (1) melakukan perencanaan karier yang jelas, baik yang dilakukan oleh instansi maupun PNS yang bersangkutan, (2) setiap instansi pemerintah harus mempunyai pola karier yang definitif sebagai arahan pegawai dalam menentukan kariernya, (3) memperbaiki metode dan substansi penilaian kompetensi dalam proses pengembangan karier PNS, dan (4) mengubah pola pengembangan karier PNS dari yang sifatnya tradisional ke sistem pengembangan karier yang sifatnya modern. Prinsip ini untuk menciptakan kadar profesionalime PNS dalam melaksanakan setiap misi instansinya di semua lembaga pemerintahan, tujuannya untuk tersedianya SDM PNS yang handal dan memadai pada semua birokrasi pemerintah (Rakhmawanto, 2010).

Proses dan pengembangan karier harus berorientasi profesionalisme yang berarti pengembangan karier pegawai tidak hanya ke arah struktural, tetapi juga mengembangkan expertise ke arah fungsional. Dengan demikian, posisi fungsional memiliki peran sebagai equal partner in structural position (Ma'arif, 2012). Dalam melaksanakan penelitian ini diperlukan dukungan data baik primer mupun sekunder, yang diperoleh baik dari dalam lingkup organisasi IPB sendiri, maupun yang didapat dari lingkup organisasi Biro Kepegawaian Setjen Kemendikbud.

\section{Metode Penelitian}

Penelitian ini dilakukan di Institut Pertanian Bogor(IPB) dan Biro Kepegawaian Setjen Kemendikbud. Pemilihan lokasi dilakukan secara sengaja. Penelitian dilakukan selama enam bulan, yakni dari bulan Mei 2013 hingga Oktober 2013.

Data yang dikumpulkan adalah data primer yang diambil dari sumber data utama, yang dilakukan dengan cara wawancara dengan para pakar melalui pengisian kuesioner. Pertanyaan yang ada berupa pertanyaan tertutup dimana pakar diberikan pilihan untuk jawaban yang akan dipilih. Data sekunder adalah data yang diperoleh dari direktorat SDM IPB, Biro Kepegawaian Setjen Kemendikbud, studi literatur menggunakan buku, internet dan jurnal serta data-data lain yang relevan dengan penelitian.

Para pakar adalah orang-orang yang memiliki kapabilitas dan pengalaman dan atau orang-orang yang terlibat secara langsung dalam kebijakan sistem karier IPB. Pakar yang dipilih adalah yang memiliki kapabilitas dan memahami dan atau mempunyai pengalaman dibidang manajemen karier. Para pakar dalam penelitian dipilih sebanyak lima orang, yaitu: (1) Wakil Rektor Bidang Sumberdaya dan Kajian Strategis IPB, (2) Direktur SDM IPB, (3) Ketua Tim Penilai Angka Kredit (TPAK) pustakawan IPB (4) Ketua TPAK arsiparis IPB dan (5) Pejabat Struktural di lingkup Biro Kepegawaian Setjen Kemendikbud.

AHP merupakan alat analisis manajemen strategik dengan pendekatan totalitas sistem seperti lingkungan, ekonomi, pemerintahan dan organisasi yang tidak bisa dianalisis hanya pada bagianbagiannya saja tetapi harus dipahami sebagai satu kesatuan. (Ma'arif, 2012). Expert Choicemerupakan salah satu software AHP yang memiliki kelebihan antara lain mampu mengintegrasikan pendapat pakar, dan tidak membatasi level dari struktur 


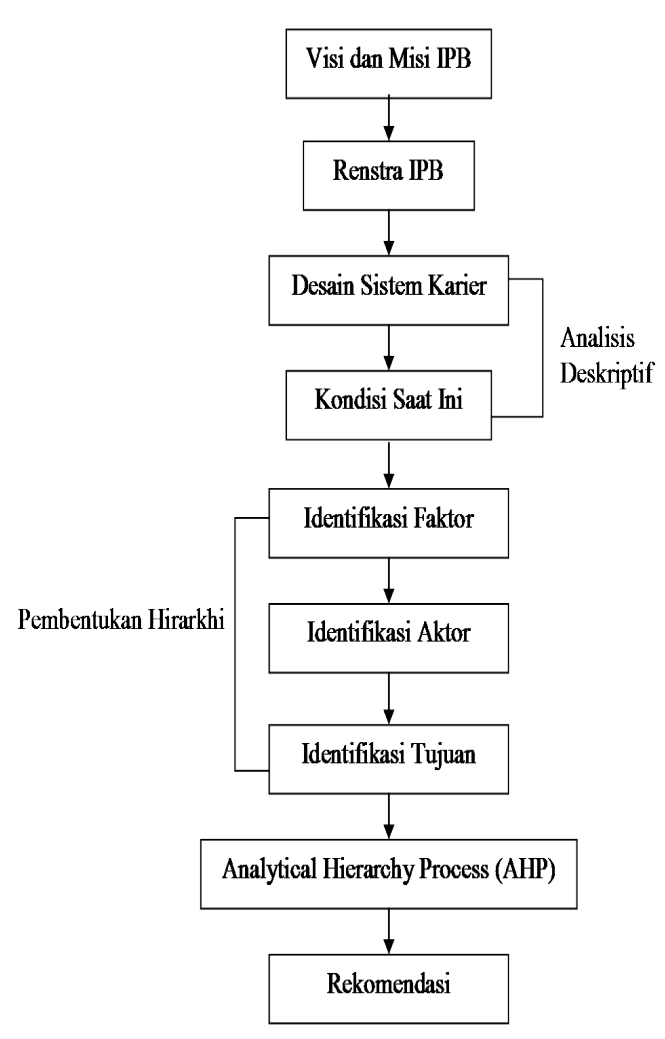

Gambar 4 Kerangka Penelitian

hirarkhi (Marimin, 2010).

\section{Hasil dan Pembahasan}

\section{Gambaran Umum Kondisi SDM IPB}

Salah satu faktor yang sangat menentukan kualitas suatu perguruan tinggi adalah kualitas sumberdaya manusia (SDM) yang dimiliki. Oleh karena itu, IPB senantiasa berkomitmen untuk terus meningkatkan kualitas SDM-nya. SDM IPB terdiri atas tenaga pendidik (dosen) dan tenaga kependidikan. Tenaga kependidikan terdiri dari pejabat struktural, pejabat fungsional tertentu dan fungsional umum. Sebagai institusi milik pemerintah, dosen dan tenaga kependidikan IPB pada umumnya berstatus PNS, namun tidak sedikit yang berstatus non-PNS atau honorer. Namun demikian, dalam penelitian ini hanya akan dideskripsikan sumberdaya manusia PNS IPB khususnya tenaga kependidikan yang berstatus fungsional umum.

Analisis Deskriptif Pengembangan Karier PNS Fungsional Umum di IPB
Rancangan Undang Undang Aparatur Sipil Negara (RUU ASN) yang sedang dibahas pemerintah merupakan suatu langkah positif yang harus diberi apresiasi. Pembentukan RUU ASN merupakan perubahan dari Undang-Undang Nomor 43 Tahun 1999 tentang Pokok-Pokok Kepegawaian. Aturan yang lama ini dianggap belum mampu melahirkan aparat negara yang profesional sehingga disusun aturan baru yang lebih komprehensif untuk dapat menciptakan kondisi aparatur yang lebih berkompeten dan profesional. Melalui Rancangan UU yang baru ini, manajemen kepegawaian diperbaharui. RUU ini disusun dengan konsep manajemen strategis sumber daya manusia dan bertujuan untuk mengembangkan potensi human capital.

RUU ASN adalah suatu upaya legal yang komprehensif. Upaya legal ini disusun dalam menjawab tuntutan untuk menciptakan manajemen kepegawaian yang lebih profesional. Keseluruhan sistem kepegawaian akan mengedepankan kinerja dan profesionalisme ASN. Profesionalme tersebut sesuai dengan definisi dalam RUU ASN, Bab I Ketentuan Umum Pasal 1, ayat: (10) Pegawai Jabatan Administrasi adalah Pegawai ASN yang menduduki Jabatan Administrasi pada instansi; (11) Jabatan Fungsional adalah sekelompok jabatan yang berisi tugas pokok dan fungsi berkaitan dengan pelayanan fungsional yang berdasarkan pada keahlian dan keterampilan tertentu; (12) Pegawai Jabatan Fungsional adalah Pegawai ASN yang menduduki Jabatan Fungsional pada instansi.

Draft RUU ASN menyebutkan adanya pemberlakuan sistem rekruitmen dan promosi aparatur sipil negara berbasis kompetensi, bersifat transparan, dan dilayani secara sentralisasi. Sehingga mendorong mobilitas aparatur antar instansi dan antara pusat dan daerah. Di RUU ini juga akan diatur sistem gaji berbasis kinerja, dimana gaji pokok lebih besar dari tunjangan yang diperoleh. Gaji sesuai dengan beban kerja dan tanggung jawab yang dipikul oleh pegawai.

Pada bulan Maret sampai April 2013 Direktorat SDM IPB telah melakukan kegiatan pemutakhiran data PNS tenaga kependidikan. Dari kegiatan tersebut diperoleh data: seluruh PNS tenaga kependidikan IPB sampai September 2013 berjumlah 1.500 orang. Sedangkan prosentase PNS pejabat fungsional tertentu di IPB terhadap jumlah total PNS tenaga kependidikan IPB dapat dilihat pada Tabel 1.

Dengan demikian sebanyak 1.286 orang atau 
Tabel 1 Prosentase PNS Pejabat Fungsional Tertentu di IPB

\begin{tabular}{llcc}
\hline No & $\begin{array}{c}\text { Jabatan Fungsional } \\
\text { Tertentu }\end{array}$ & $\begin{array}{c}\text { Jumlah } \\
\text { (orang) }\end{array}$ & $\begin{array}{c}\text { \% Terhadap } \\
\text { Total PNS Tenaga } \\
\text { Kependidikan IPB }\end{array}$ \\
\hline 1 & Pustakawan & 31 & 2,1 \\
2 & Arsiparis & 25 & 1,7 \\
3 & Pranata Humas & 8 & 0,5 \\
4 & $\begin{array}{l}\text { Pranata Laboratori- } \\
\text { um Pendidikan }\end{array}$ & 150 & 10,0 \\
\hline Jumlah Total & 214 & 14,3 \\
\hline
\end{tabular}

$85,7 \%$ adalah PNS fungsional umum termasuk pejabat struktural, yang secara selektif akan dialihfungsikan menjadi PNS pejabat fungsional tertentu. Berdasarkan uraian diatas maka $85,7 \%$ PNS fungsional umum IPB secara bertahap juga dapat direposisi menjadi seperti istilah dalam RUU ASN, yaitu Pegawai Jabatan Administrasi dan Pegawai Jabatan Fungsional. Tentunya reposisi tersebut melalui proses sosialisasi dan disesuaikan dengan kompetensi dan minat PNS fungsional umum di IPB.

\section{Perumusan Struktur Hirarkhi Pengembangan Karier PNS Fungsional Umum di IPB}

Penulis merumuskan struktur hirarkhi Strategi Pengembangan Karier Jabatan fungsional Tertentu PNS Fungsional Umum di IPB menjadi lima tingkatan/level hirarkhi, dalam rangka mencapai fokus utama. Tingkatan hirarkhi meliputi: 1) level pertama adalah fokus utama yang ingin dituju, yaitu Strategi Pengembangan Karier PNS Fungsional Umum di IPB, 2) level kedua adalah faktor pendukung untuk pengembangan karier PNS fungsional umum di IPB, terdiri dari lima hal penting meliputi pengorganisasian, kerjasama, fleksibilitas, KSA (Knowledge, Skills, Attitude) dan minat. Faktor KSA juga dapat berarti kompetensi dan kepribadian PNS yang sebaiknya dari awal rekrutmen sudah diagendakan. Hal ini sesuai dengan hasil pengkajian oleh Purwoko (2012) mengenai Peningkatan Produktivitas Pegawai Melalui Rekrutmen berdasarkan Karakteristik Kepribadian Individu. Kajian ini menyimpulkan bahwa antara karakteristik kepribadian dari pegawai yang ada cukup sesuai dengan pekerjaan/jabatan mereka, dengan memberikan pekerjaan yang menekankan pada aspek-aspek keperibadian yang hendak ditingkatkan tingkat dominannya, 3) level ketiga adalah aktor yang terlibat dalam pengambilan keputusan dalam upaya pengembangan karier jabatan fungsional tertentu PNS fungsional umum di IPB, terdiri dari lima aktor meliputi: Wakil Rektor Bidang Sumberdaya dan Kajian Strategis IPB, Direktur Sumberdaya Manusia IPB, Ketua Tim Penilai Angka Kredit (TPAK) Pustakawan IPB, Ketua TPAK Arsiparis IPB dan Pejabat Struktural di lingkup Biro Kepegawaian Kemendikbud, 4) level keempat adalah tujuan dalam rangka mencapai pengembangan karier jabatan fungsional tertentu PNS fungsional umum di IPB, terdiri dari tiga tujuan yaitu: profesionalisme, peningkatan kompetensi, dan alihfungsi tugas/ jabatan dan 5) level kelima adalah alternatif strategi yang dapat digunakan dalam mencapai goal/fokus, terdiri dari lima alternatif strategi meliputi: Assesment Center, sistem diklat, mutasi dan rotasi, sasaran kerja pegawai dan penambahan jabatan fungsional tertentu.

\section{Analisis Hasil Pengolahan Proses Hirarkhi}

Pengolahan data terhadap struktur hirarkhi dilakukan dengan melakukan pembobotan pada setiap unsur pada setiap tingkat oleh pakar yang telah ditetapkan sebanyak lima orang. Kemudian dilakukan perhitungan bobot pendapat dari setiap pakar, dan perhitungan Inconsistency Ratio(IR) yang menunjukkan hasil isian kuesioner telah memenuhi syarat IR $\leq 10 \%$, sehingga dapat digunakan untuk analisis data. Hasil penilaian kelima pakar dalam memberikan pendapat terhadap struktur hirarkhi, selanjutnya digabungkan dan diolah kembali sehingga didapatkan hasil perhitungan vertikal dan horisontal.

Tabel 2 Bobot dan Prioritas Faktor terhadap Fokus Utama

\begin{tabular}{lcc}
\hline \multicolumn{1}{c}{ Faktor } & $\begin{array}{c}\text { Bobot } \\
\text { Nilai }\end{array}$ & Prioritas \\
\hline Pengorganisasian & 0,357 & 1 \\
KSA (Knowledge, Skills, Attitude) & 0,281 & 2 \\
Kerjasama & 0,195 & 3 \\
Fleksibilitas & 0,096 & 4 \\
Minat & 0,070 & 5 \\
\hline
\end{tabular}




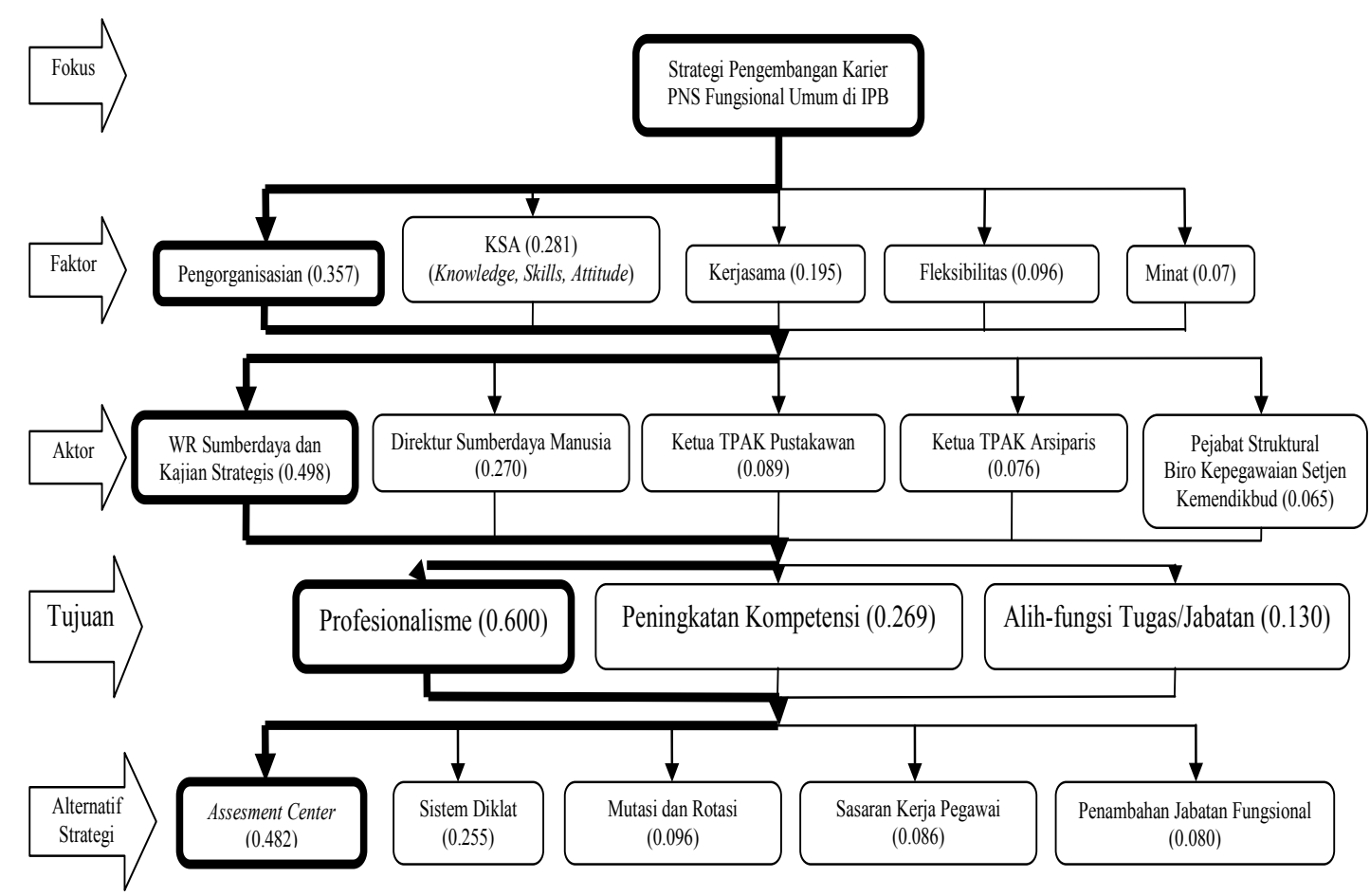

Gambar 5 Skema Hirarkhi AHP Hasil Pengolahan Vertikal

\section{Pengolahan Vertikal}

Pengolahan data secara vertikal dilakukan untuk mengetahui pengaruh setiap unsur pada level hirarkhi tertentu terhadap fokus: pengembangan karier jabatan fungsional tertentu PNS fungsional umum di IPB pada level pertama dan level kedua. Skema hirarkhi dapat dilihat pada Gambar 5.

\section{Analisis Faktor Terhadap Fokus: Pengembangan Karier PNS Fungsional Umum di IPB}

Pengembangan karier PNS fungsional umum di IPB didasarkan pada faktor yang mempengaruhi dari IPB secara organisasional dan disesuaikan dengan batas masa kerja PNS fungsional umum yang bersangkutan. Berdasarkan hasil pengolahan data kuisioner para pakar sebagai responden didapatkan bahwa faktor pengorganisasian $(0,357)$ menjadi prioritas utama yang dapat dipertimbangkan dalam penyusunan strategi pengembangan karier PNS fungsional umum di IPB (Tabel 2).

Faktor pengorganisasian $(0,357)$ merupakan prioritas utama yang dapat dipertimbangkan dalam penyusunan strategi pengembangan karier jabatan fungsional tertentu PNS fungsional umum di IPB. Faktor pengorganisasian sangat penting dan perlu diperhatikan, karena suatu organisasi (IPB) harus memiliki kemampuan meng organisasikan tujuan dan sasaran yang ingin dicapai kepada anggota organisasi (PNS IPB yang masih berstatus fungsional umum) melalui pengembangan karier mereka, dengan mengagendakan pembelajaran organisasional. Tentu pengorganisasian agenda tersebut disesuaikan dengan masa kerja anggotanya. Hasil analisis pengolahan data yang menghasilkan faktor prioritas utama yaitu Pengorganisasian $(0,357)$ didukung oleh hasil penelitian Rakhmawanto (2010) mengenai Career System Sebagai Upaya Menciptakan Profesionalisme Pegawai Di Lingkungan Birokrasi Pemerintah, yang menyimpulkan bahwa terdapat terkaitan antara penerapan sistem karier dengan kemampuan melakukan perencanaan karier (pengorganisasian) yang jelas, baik yang dilakukan oleh instansi maupun PNS yang bersangkutan.

Faktor kedua dan ketiga yang dapat menjadi pertimbangan adalah KSA $(0,281)$ dan Kerjasama $(0,195)$. Artinya IPB harus memiliki kemampuan meningkatkan faktor Knowledge (Pengetahuan), Skills berupa keterampilan mengolah informasi, berkomunikasi, mengkordinasikan pekerjaan, dan menganalisis setiap permasalahan dalam tugas, serta meningkatkan faktor Attitude berupa sikap yang relatif konsisten terhadap gagasan yang dikeluarkan, terhadap setiap PNS yang masih 
Tabel 3 Bobot dan Prioritas Aktor terhadap Fokus Utama

\begin{tabular}{lcc}
\hline \multicolumn{1}{c}{ Faktor } & Bobot Nilai & Prioritas \\
\hline Wakil Rektor Sumberdaya dan Kajian Strategis IPB & 0,498 & 1 \\
Direktur Sumberdaya Manusia IPB & 0,270 & 2 \\
Ketua Tim Penilai Angka Kredit (TPAK) Pustakawan IPB & 0,089 & 3 \\
Ketua Tim Penilai Angka Kredit (TPAK) Arsiparis IPB & 0,076 & 4 \\
Pejabat Struktural di lingkup Biro Kepegawaian Setjen Kemendikbud & 0,065 & 5 \\
\hline
\end{tabular}

berstatus fungsional umum di IPB. KSA tersebut dapat dioptimalkan PNS fungsional umum, jika ditambah kemampuan IPB menumbuhkan semangat bekerjasama dalam tim (team work) sehingga mereka dapat mengembangkan kariernya kedepan sesuai dengan kompetensi, prestasi kinerja dan kemampuan beradaptasi yang dimilikinya.

\section{Analisis Aktor Terhadap Fokus: Pengembangan Karier PNS Fungsional Umum di IPB}

Berdasarkan hasil penelitian didapatkan bahwa Wakil RektorSumberdayadan Kajian Strategis IPB $(0,498)$ menjadi aktor yang paling berpengaruh dalam penyusunan strategi pengembangan karier PNS fungsional umum di IPB (Tabel 3).

Peran Wakil Rektor Sumberdaya dan Kajian Strategis IPB tidak hanya sebagai representasi dari Rektor sebagai Pimpinan Institusi IPB, tetapi juga sebagaipenggerakdan pendorong pengembangankarier PNS fungsional umum di IPB, dan didukung pejabat dibawahnya karena beliau memiliki kewenangan terbesar dalam kegiatan pengembangan karier PNS fungsional umum di IPB, karena mewakili Rektor sebagai Pejabat Pembina Kepegawaian (PPK) dan pengambil keputusan dalam Manajemen Sumberdaya Manusia (MSDM) di lingkup IPB. Menurut Irianto (2001) MSDM memiliki prinsip kepemimpinan yang bersifat partisipatif. Jika mencermati prinsip MSDM pertama yang memposisikan unsur manusia sebagai pihak yang bersifat aktif, prinsip kedua MSDM juga memposisikan figur pemimpin sebagai pihak yang aktif dan tidak sekadar bersifat situasional. Secara teoritis, kepemimpinan terbaik adalah dengan menyesuaikan diri terhadap semua perubahan bentuk situasional.

Namun kepemimpinan yang terbaik adalah kemampuan penyesuaian diri pemimpin secara aktif disertai tingkat pelibatan diri pada semua level organisasi secara intensif dan dengan kemampuan membentuk lingkungan yang kreatif. Oleh karena itu pemimpin yang menjadi pengambil keputusan sekaligus aktor internal IPB diharapkan mempunyai kemampuan tersebut. Menurut Tiffani dan Rustam (2012) MSDM merupakan bagian dari manajemen organisasi yang memfokuskan diri pada unsur sumberdaya manusia, serta mempunyai tugas untuk mengelola unsur manusia secara baik agar diperoleh tenaga kerja yang puas akan pekerjaannya.

Dalam tugasnya MSDM dapat dikelompokkan atas tiga fungsi, yaitu: 1) fungsi manajerial: perencanaan, pengorganisasian, pengarahan, danpengendalian;2)fungsi operasional: pengadaan, pengembangan, kompensasi, pengintegrasian, pemeliharaan, dan pemutusan hubungan kerja; 3) fungsi ketiga adalah kedudukan manajemen sumber daya manusia dalam pencapaian tujuan organisasi perusahaan secara terpadu. Dari penjelasan diatas dapat disimpulkan bahwa MSDM mempunyai definisi sebagai suatu perencanaan, pengorganisasian, pengarahan, dan pengawasan atas pengadaan, pengembangan, kompensasi, pengintegrasian, pemeliharaan, dan pemutusan hubungan kerja dengan maksud untuk mencapai tujuan organisasi perusahaan secara terpadu, serta memastikan bahwa seluruh pegawai diberi kesempatan yang sama untuk melakukan pengembangan karier.

Kemudian aktor kedua yaitu Direktur Sumberdaya Manusia IPB yang salah satu tugas pokoknya adalah menerima penugasan dan arahan dari Wakil Rektor bidang Sumberdaya dan Kajian Strategis dalam pengembangan sistem peningkatan kompetensi dan kepakaran SDM. Artinya Direktur SDM IPB adalah aktor yang terlibat langsung dalam pengelolaan pengembangan dan peningkatan kompetensi dan kepakaran SDM, dalam konteks penelitian ini adalah pengembangan karier PNS fungsional umum di IPB. Sedangkan aktor ketiga dan keempat yaitu ketua TPAK Pustakawan dan Arsiparis adalah lebih sebagai percontohan karena Pustakawan dan 
Tabel 4 Bobot dan Prioritas Tujuan terhadap Fokus Utama

\begin{tabular}{lcc}
\hline \multicolumn{1}{c}{ Tujuan } & Bobot Nilai & Prioritas \\
\hline Profesionalisme & 0,600 & 1 \\
Peningkatan Kompetensi & 0,269 & 2 \\
Alih Fungsi Tugas/Jabatan & 0,130 & 3 \\
\hline
\end{tabular}

Sumber: data primer AHP diolah, 2013

Arsiparis adalah jabatan fungsional tertentu PNS Tenaga Kependidikan di IPB yang proses penilaian angka kreditnya sudah mandiri. Dalam arti ketua dan anggota tim penilai angka kredit berada di lingkup IPB sendiri, kemudian hasil penilaian angka kredit tersebut diserahkan kepada instansi pusat pembina jabatan fungsional tertentu tersebut untuk ditindaklanjuti.

Aktor kelima adalah Pejabat Struktural di lingkup Biro Kepegawaian Setjen Kemendikbud. Menurut hasil pengamatan penulis, meskipun pengembangan karier PNS fungsional umum di IPB memang berada di bawah wewenang internal IPB, namun mengenai koordinasi dan pembinaan jabatan fungsional tertentu tetap dikomunikasikan dengan Biro Kepegawaian Setjen Kemendikbud, sebagai instansi pembina kepegawaian tingkat pusat dan yang menjembatani proses pengembangan karier sumberdaya manusia antara IPB dan BKN.

Hasil analisis penelitian mengenai pengaruh aktor terhadap pengembangan karier PNS fungsional umum di IPB, yang menempatkan aktor utama sampai dengan keempat adalah aktor internal IPB, didukung oleh pernyataan Irianto (2001), yaitu bahwa pengertian karier meliputi elemen obyektif yang berkenaan dengan kebijakan-kebijakan pekerjaan atau posisi jabatan yang ditentukan pimpinan organisasi. Dengan demikian diharapkan akan terjadi hubungan sinergis antara elemen obyektif dalam hal ini IPB sebagai organisasi, dengan PNS fungsional umum sebagai elemen subyektif demi masa depan IPB yang lebih baik.

Analisis Tujuan Terhadap Fokus: Pengembangan Karier PNS Fungsional Umum di IPB

Berdasarkan hasil pengolahan vertikal Profesionalisme $(0,600)$ menjadi tujuan utama dalam pengembangan karier PNS fungsional umum di IPB. Seperti dapat dilihat pada Tabel 4. Profesional mengandung makna PNS bekerja sesuai profesi atau fungsinya. Hasil pengolahan vertikal yang menghasilkan prioritas tujuan utama profesionalisme $(0,600)$, prioritas kedua peningkatan kompetensi $(0,269)$ dan prioritas ketiga alih fungsi tugas/jabatan $(0,130)$, dalam rangka pengembangan karier PNS fungsional umum di IPB tersebut, didukung oleh hasil penelitian Maarif (2010) mengenai Membangun Profesionalisme Aparatur Untuk Mengantisipasi Kebutuhan Sektor Pelayanan Publik yang menyimpulkan bahwa visi dalam konteks pembangunan bidang kepegawaian di masa yang akan datang adalah untuk mempersiapkan PNS yang profesional, mampu bersaing dan mampu mengantisipasi perkembangan dunia yang pesat di berbagai aspek kehidupan (kompeten) sehingga mampu meningkatkan mutu pelayanan serta kinerja yang tinggi (yang dapat dicapai melalui alih fungsi tugas/jabatan).

Dalam rangka mencapai tujuan nasional, dibutuhkan adanya PNS dengan mutu profesionalisme yang memadai, berdayaguna dan berhasilguna didalam melaksanakan tugas umum pemerintahan dan pembangunan. maka suatu keniscayaan bagi pemerintah termasuk IPB untuk memperkuat jabatan fungsional tertentu, terutama dari segi peningkatan kemampuan dan tunjangan. Dalam materi Diklat PO, disebutkan bahwa tujuan penetapan jabatan fungsional adalah 1) peningkatan Produktivitas Kerja PNS, 2) peningkatan Produktivitas Unit kerja, 3) peningkatan Karier PNS dan 4) peningkatan Profesionalisme PNS. Peningkatan kompetensi dan alih fungsi tugas/ jabatan sebagai prioritas tujuan kedua dan ketiga, sesuai dengan hasil penelitian mengenai Pengembangan Jabatan Fungsional di Lingkungan Pemerintah Daerah

Tabel 5 Bobot dan Prioritas Alternatif Strategi terhadap Fokus Utama

\begin{tabular}{lcc}
\hline \multicolumn{1}{c}{ Alternatif Strategi } & Bobot Nilai & Prioritas \\
\hline Assesment Center & 0,482 & 1 \\
Sistem Diklat & 0,255 & 2 \\
Mutasi dan Rotasi & 0,096 & 3 \\
Sasaran Kerja Pegawai & 0,086 & 4 \\
$\begin{array}{l}\text { Penambahan Jabatan } \\
\text { Fungsional Tertentu }\end{array}$ & 0,080 & 5 \\
\hline
\end{tabular}


(Pemda) oleh Sulistiyani dan Sukmayeti (2007), yang membahas manajemen SDM di lingkungan pemerintah daerah mengenai pengembangan kelompok jabatan fungsional. Inspirasi yang melandasi pentingnya pengembangan jabatan fungsional karena mengingat rumpun jabatan fungsional merupakan jabatan karir, khususnya untuk mendukung beroperasinya mesin pelayanan di daerah. Sebagaimana dipahami bahwa peran dan fungsi jabatan fungsional dapat mencerminkan kinerja pelayanan karena terkait secara langsung dengan sistem pelayanan masyarakat yang menjadi bagian dari urusan wajib daerah.

\section{Analisis Alternatif Strategi Terhadap Fokus: Pengembangan Karier PNS Fungsional Umum di IPB}

Berdasarkan hasil penelitian Assesment Center $(0,482)$ menjadi alternatif strategi yang paling direkomendasikan dalam pengembangan karier PNS fungsional umum di IPB. Hasilnya seperti dapat dilihat pada Tabel 5. Kedua alternatif strategi teratas yaitu assesment center $(0,482)$ dan sistem diklat $(0,255)$ bobot nilainya cukup jauh dari ketiga prioritas alternatif di bawahnya, menunjukkan bahwa keduanya merupakan prioritas alternatif strategi yang sangat direkomedasi oleh para pakar dalam pengembangan karier PNS fungsional umum di IPB. Hasil ini juga didukung oleh kajian oleh Winarsih dan Ratminto (2011) menyatakan assessment center tidak hanya untuk memilih calon terbaik diantara kandidat yang ada, tetapi juga menempatkan PNS fungsional umum tersebut pada posisi yang paling optimal. Misalnya, pegawai dengan keahlian dalam komunikasi lisan akan ditempatkan pada pekerjaan yang sering menuntut presentasi, demikian halnya PNS fungsional umum yang lemah dalam keahlian bidang perencanaan akan ditempatkan dibawah pimpinan yang memiliki keahlian perencanaan yang kuat.

Dalam materi Diklat P0 (2013) disebutkan bahwa dalam rangka meningkatkan kinerja pegawai diperlukan adanya suatu pemahaman yang jelas mengenai apa yang diharapkan oleh organisasi dan pegawai. Pegawai dapat bekerja secara maksimal apabila dia mengetahui arah dan tujuan organisasi dan apa peranan yang dimainkannya dalam pencapaian tujuan tersebut. Selain itu, peran dan tanggung jawab yang diberikan oleh organisasi harus sesuai dengan kompetensi yang dimiliki pegawai. Apabila dirasakan ada kekurangan (gap) maka diberikan pelatihan meningkatkan kompetensi pegawai. Transparansi dan kejelasan dalam pengembangan kompetensi, peran dan tanggung jawab pegawai harus disusun dalam suatu pola karier yang jelas, transparan dan dapat diakses oleh pegawai.

Menurut Irianto (2001) faktor lain yang mendukungmeningkatnyakualitas PNS adalahupaya pendidikan dan pelatihan secara berkesinambungan. Eksistensi PNS perlu mendapat perhatian khusus, berkaitan dengan strategi peningkatan kualitas dan kompetensinya. Peningkatan kompetensi PNS dalam mengemban tugas atau jabatan melalui pendidikan dan pelatihan adalah berorientasi pada standar kompetensi jabatan yang disesuaikan dengan kebutuhan organisasi. Setelah melalui kegiatan pendidikan dan pelatihan, manajemen puncak dalam organisasi pemerintah perlu memperhatikan sistem pengendalian dalam rangka meningkatkan kualitas PNS, karena melalui pengendalian, pemimpin dapat memastikan bahwa PNS yang ada bekerja sesuai tujuan organisasi dengan menggunakan kompetensi yang dimiliki.

Pengendalian ini meliputi penilaian kinerja, yaitu berkenaan dengan penilaian tingkat pencapaian hasil yang diperoleh seorang PNS dalam melaksanakan tugas pokok dan fungsinya. Penilaian kinerja terhadap masing-masing aparatur menjadi kewenangan pejabat yang berwenang dalam tiap unit instansi atau organisasi. Penilaian kinerja dapat dilakukan berdasarkan perencanaan pada tingkat individu dan tingkat unit organisasi dengan memperhatikan target dan hasil yang dicapai. Hasil penilaian kinerja ini nantinya akan berkaitan dengan pengembangan karier (pengangkatan jabatan, kenaikan pangkat, promosi) dan juga pemberian kompensasi (tunjangan kinerja) atau remunerasi.

Menurut Ma'arif (2010) upaya peningkatan kompetensi aparatur guna mengantisipasi kebutuhan sektor pelayanan publik dapat difokuskan pada peningkatan profesionalisme aparatur yang dapat dilakukan melalui: 1) transformasi manajemen dalam upaya mencari dan mempertahankan kunci-kunci keunggulan bersaing, 2) pemberdayaan sumberdaya manusia secara terencana dan berkesinambungan, terutama pemimpin dan aparatur secara umum, 3) penetapan standar jabatan dan kompetensi berikut prosedur pengukurannya, 4) pembangunan assessment center sebagai wahana untuk mengukur 
future competencies dari setiap pegawai, dan 5) pembangunan value aparatur yang mencakup spirit sebagai public servant dan trust.

\section{Implikasi Manajerial}

Dari hasil penelitian dan analisis yang telah dilakukan mengenai strategi pengembangan karier PNS fungsional umum di IPB, faktor yang menjadi prioritas utama adalah Pengorganisasian, aktor yang paling mempengaruhi pengembangan karier PNS fungsional umum di IPB adalah Wakil Rektor Sumberdaya dan Kajian Strategis, tujuan utama yang menjadi prioritas adalah Profesionalisme dan alternatif strategi yang paling direkomendasikan adalah Assesment Center.

Di sisi lain sampai dengan September 2013 dari 1.500 PNS tenaga kependidikan, yang berpendidikan S1 ke atas berjumlah 327 orang $(21,8 \%)$ namun penempatannya belum semua sesuai kompetensi sehingga berpengaruh pada profesionalisme dan kualitas SDM. Berdasarkan hal itu, maka strategi untuk pengembangan karier PNS fungsional umum di IPB tindak lanjutnya antara lain:

Membuat program pengembangan karier dan peningkatan profesionalisme PNS fungsional umum di IPB, seperti berikut ini: 1) Diklat Teknis dilaksanakan untuk memberikan pengetahuan dan keterampilan teknis yang mendukung pelaksanaan tugas jabatan PNS fungsional umum di IPB, 2) Diklat Penjenjangan Fungsional dilaksanakan untuk memberikan pengetahuan dan keterampilan teknis fungsional yang mendukung pelaksanaan tugas fungsio nal pada jenjang tertentu. Diklat ini sebagai salah satu syarat untuk diangkat dalam jenjang jabatan fungsional tertentu, 3) Pendidikan Formal dilaksanakan untuk meningkatkan pengetahuan dan dayanalar, analisis, dankonsepsi PNS sehinggamampu melaksanakan tugas organisasi sesuai perkembangan regulasi serta ilmu pengetahuan dan teknologi, 4) Magang merupakan salah satu program pelatihan dan pengembangan pegawai. Magang bertujuan untuk memberikan pengetahuan dan keterampilan pada tugas tugas yang akan diembannya dengan cara mengerjakan pekerjaan-pekerjaan yang ada di tempat magang, 5) Mutasi Jabatan dilaksanakan untuk memberikan wawasan dan tugas-tugas lain di luar bidang tugas sebelumnya sehingga PNS tersebut terdorong untuk selalu meningkatkan kinerja organisasi, 6) Studi banding dilaksanakan untuk memberikan wawasan kepada PNS terhadap keberhasilan tugas yang dilaksanakan oleh lembaga atau orang lain sehingga dapat dijadikan pendorong bagi peningkatan kinerja organisasi.

Alternatif strategi utama yaitu pembentukan assesment center dapat dilakukan oleh aktor yang paling berpengaruh yaitu Wakil Rektor Sumberdaya dan Kajian Strategis dengan melaksanakan langkah-langkah strategis sebagai berikut: 1) Evaluasi organisasional. Evaluasi ini berhubungan dengan kebutuhan organisasi IPB secara keseluruhan diikuti dengan identifikasi bagaimana pendidikan dan pelatihan dapat dieksploitasi sedemikian rupa untuk mencapai tujuan IPB sebagai suatu organisasi. Analisis ini berupaya memahami apa yang sesungguhnya dibutuhkan oleh organisasi, 2) Evaluasi jabatan. Evaluasi jabatan ini dapat dikaitkan dengan kebutuhan terhadap pekerjaan tertentu dalam organisasi IPB dan dapat digunakan sebagai informasi tentang substansi utama pekerjaan tersebut untuk selanjutnya dikembangkan standar kinerja. Selain itu juga dimungkinkan untuk mengidentifikasi tingkat KSA (Knowledge, Skills dan Attitude) yang dibutuhkan untuk mencapai standar yang telah ditetapkan. 3) Evaluasi personal. Pada tingkat evaluasi ini pimpinan dapat mengkaitkan dengan kebutuhan individual dalam organisasi dan sejauh mana kinerja yang telah dicapainya.

Hasil dari ketiga evaluasi tersebut dapat disimpan dalam rekam jejak PNS, yang berisi tentang catatan tempat bekerja, Diklat, prestasi dan hukuman yang pernah diberikan selama bekerja sebagai PNS sampai pensiun. Bagi yang berprestasi pada saat tertentu diberikan penghargaan/insentif dan saat pensiun dapat dipakai sebagai pertimbangan untuk diberikan penghargaan khusus. Bila ada catatan hukuman perlu dipertimbangkan untuk penundaan peningkatan karier PNS, yang harus diisi secara jujur dan benar oleh tim penilai yang terdiri dari atasan langsung yang dikontrol oleh lembaga yang bersifat independent. Rekam jejak ini dapat berfungsi sebagai bahan pendukung dalam pembentukan assesment center.

\section{Kesimpulan}

Berdasarkan analisis hasil penelitian dan pengamatan tentang strategi pengembangan karier PNS fungsional umum di IPB, maka dapat disimpulkan 
bahwa pengorganisasian sebagai faktor yang menjadi prioritas utama dapat dicapai melalui evaluasi kegiatan tugas jabatan seperti yang terdapat pada formulir SKP (Sasaran Kerja Pegawai), disesuaikan dengan kompetensi berupa pengalaman kerja, pendidikan terakhir, KSA (Knowledge, Skills dan Attitude) serta minat setiap PNS fungsional umum di IPB. Wakil Rektor Sumberdaya dan Kajian Strategis sebagai aktor yang paling berpengaruh dalam strategi pengembangan karier jabatan fungsional tertentu PNS fungsional umum di IPB, dalam rangka mencapai tujuan utama yaitu profesionalisme dapat segera membentuk panitia khusus rencana pendirian assesment center yang terdiri dari pihak internal IPB yang memiliki kompetensi yang baik dalam pengembangan karier. Sebelum assesment center dibentuk melalui hasil evaluasi seperti yang disebutkan dalam implikasi manajerial di atas, terlebih dahulu hasil pemuktahiran data kompetensi PNS fungsional umum September 2013 segera disesuaikan dengan jabatan fungsional tertentu yang dapat ditawarkan di IPB. Hasil dari ketiga evaluasi tersebut dapat disimpan dalam rekam jejak PNS, yang berisi tentang catatan tempat bekerja, Diklat, prestasi dan hukuman yang pernah diberikan selama bekerja sebagai PNS sampai pensiun. Bagi yang berprestasi pada saat tertentu diberikan penghargaan/insentif dan saat pensiun dapat dipakai sebagai pertimbangan untuk diberikan penghargaan khusus.

Jabatan fungsional tertentu non dosen selain empat (Pustakawan, Arsiparis, Pranata Humas dan PLP) yang sudah berjalan, dan dapat ditawarkan kepada PNS fungsional umum di IPB karena telah memenuhi persyaratan antara lain telah tersedia sumberdaya manusia yang kompeten dan terdapat unit kerja sebagai institusi koordinator atau pembina adalah: 1) Analis Kepegawaian, yaitu PNS fungsional umum yang telah mengikuti Diklat Analis Kepegawaian Tingkat Ahli pada tanggal 23 Oktober sampai 13 Nopember 2013, diikuti oleh 32 peserta yang berpendidikan minimal S1 di IPB dengan BKN sebagai penyelenggara, 2) Peneliti atau Perekayasa, yaitu PNS umum yang memang sudah bekerja sebagai peneliti atau perekayasa di Pusat-Pusat di bawah Lembaga Penelitian dan Pengembangan Masyarakat (LPPM) IPB, 3) Pengelola Pengadaan Barang/Jasa Pemerintah, yaitu PNS fungsional umum yang telah mengikuti Diklat Sertifikasi Pengadaan Barang/Jasa Pemerintah, serta lulus ujian dan memperoleh sertifikat, dan 4) Pranata Komputer atau
Pengembang Teknologi Pembelajaran, yaitu PNS fungsional umum yang bekerja sebagai teknisi komputer di setiap unit kerja IPB atau yang bekerja di DIDSI (Direktorat Integrasi Data dan Sistem Informasi) IPB.

\section{Daftar Pustaka}

Azwar S. 2007. Metode Penelitian. Yogyakarta (ID): Pustaka Pelajar

Hubeis M, Najib M. 2008. Manajemen Strategik dalam Pengembangan Daya Saing Organisasi. Jakarta (ID): Elex Media Komputindo

Irianto J. 2001. Prinsip-prinsip Dasar Manajemen Pelatihan (Dari Analisis Kebutuhan Sampai Evaluasi Program Pelatihan). Jakarta (ID): Insani Cendekia,

Laporan Akuntabilitas Kinerja Deputi Program dan Reformasi Birokrasi. 2012. Kementerian Pendayagunaan Aparatur Negara dan Reformasi Birokrasi.

Maarif M. Syamsul, Kartika L. 2012. Manajemen Kinerja Sumber Daya Manusia Implementasi Menuju Organisasi berkelanjutan. Bogor (ID): IPB Press.

Maarif MS. 2010 Membangun Profesionalisme Aparatur Untuk Mengan tisipasi Kebutuhan Sektor Pelayanan Publik: Jurnal Kebijakan dan Manajemen PNS. Pusat Pengkajian dan Penelitian Kepegawaian BKN.

Marimin, Maghfiroh N. 2010. Aplikasi Teknik Pengambilan Keputusan dalam Manajemen Rantai Pasok. Bogor (ID): IPB Press

Purwoko AP. 2012. Peningkatan Produktivitas Pegawai Melalui Rekrutmen Berdasarkan Karakteristik Kepribadian Individu: Jurnal Kebijakan dan Manajemen PNS. Pusat Pengkajian dan Penelitian Kepegawaian BKN.

Rakhmawanto A. 2010. Career System Sebagai Upaya Menciptakan Profesionalisme Pegawai Di Lingkungan Birokrasi Pemerintah: Jurnal Kebijakan dan Manajemen PNS 4. Pusat Pengkajian dan Penelitian Kepegawaian BKN.

Rancangan Undang Undang Aparatur Sipil Negara. Draf RUU 17 Juli 2013

Sulistiyani AT, Sukmayeti E. Pengembangan Jabatan Fungsional di Lingkungan Pemerintah Daerah: Jurnal Kebijakan dan Manajemen PNS Vol. 1 November 2007 Pusat Pengkajian dan Penelitian Kepegawaian BKN. 
Jurnal Penyuluhan, Maret 2014 Vol. 10 No. 1

Tiffani, Rustam. 2012 Audit Manajemen Untuk Menilai Efektivitas Fungsi Sumberdaya Manusia (Studi Kasus pada Fakultas X). Malang (ID): Universitas Brawijaya Malang
Tim Widyaswara. Materi Diklat "Peningkatan Kemampuan Manajerial Bidang Kepegawaian Tingkat Dasar (P 0)". Biro Kepegawaian Setjen Kemendikbud) 17-26 Oktober 2013 di Jakarta. 